\title{
A VENETIAN “PLAGUE MIRACLE” IN 1464 AND 1576
}

\author{
by
}

\section{WILLIAM M. SCHUPBACH*}

THE ACCEPTED theory of bubonic plague among medieval physicians is to be found in the tracts offering defences both prophylactic and therapeutic against plague composed in the years after the Black Death of 1348. ${ }^{1}$ There it was stated that the abscesses of plague (apostemata, now called buboes) were the sites of poisonous discharges emitted from the heart, liver and brain, after these had been affected by poisonous vapours in the atmosphere. The vapours, which were caused by the movements of the stars, entered the body through the pores of the skin, and the treatment recommended by physicians was in accordance with this theory. To evacuate the poison, the patient should be bled; to keep the pores closed to the air, he should avoid baths, coitus, and certain foods; to preserve the equilibrium of the humours against possible disruption from the miasmal vapours, he should lead a temperate life; and unguents were to be applied to the buboes. We now know that this treatment must have been completely ineffective, so that it is no wonder that non-physicians preferred simply to flee from infected areas, as, for example, the narrators of Boccaccio's Decameron during the Black Death, or to try to insulate their houses from the poisonous air, or to pray, worship, and to go on pilgrimages to the shrines of saints who were said to have protected people from plague in the past. These remedies were certainly no less effective than those offered by the physicians, and they continued to be used long after the end of the Middle Ages.

This state of affairs is vividly illustrated in the history of a manuscript which has recently come to light (see Figure 1). It is a leaf of dark brown parchment measuring $420 \times 345 \mathrm{~mm}$., with a horizontal crease across the middle. One side of the leaf contains thirty-five lines of prose in Venetian dialect of Italian, written in semi-humanistic script of the second half of the fifteenth century. The other side is blank, except for the figures $\frac{4}{86}$ and $V=896$ written in an eighteenth- or nineteenth-century hand, adjacent to each other on the same side of the crease. The borders of the parchment are paler than the rest, and are perforated with rust-stained holes, from which one can deduce that the manuscript was formerly kept nailed in a frame.

The text recounts an incident at the Benedictine convent of Santa Croce on the island of Giudecca, Venice, on 8 July 1464, and it must have been a similar manuscript, if not the same, that was seen and transcribed at the same convent by an anonymous writer in 1788, who described it as "an ancient sheet of parchment which

\footnotetext{
*William M. Schupbach, M.A., Wellcome Institute for the History of Medicine, 183 Euston Road, London NW1 2BP.
} 


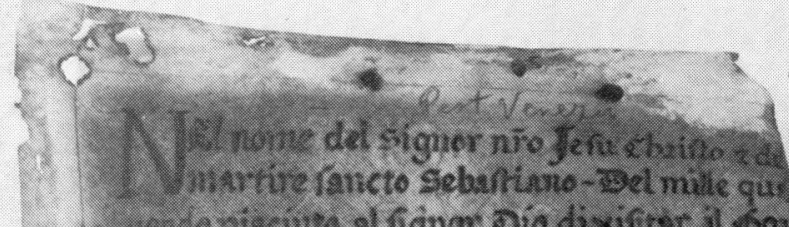

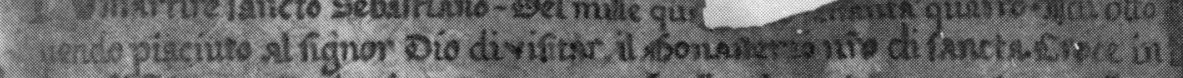

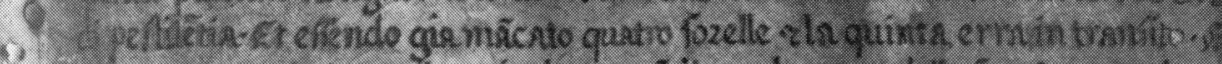

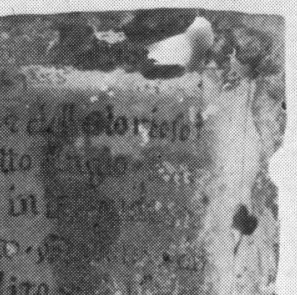

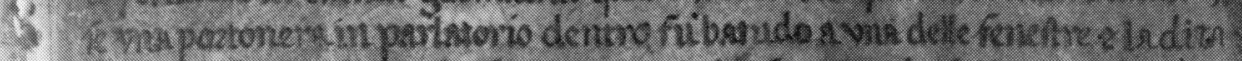

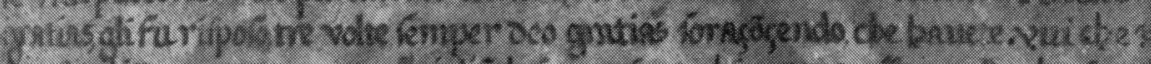

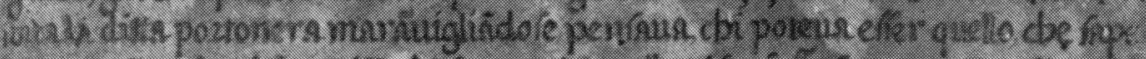

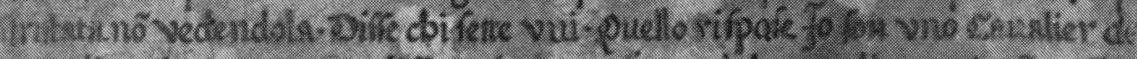

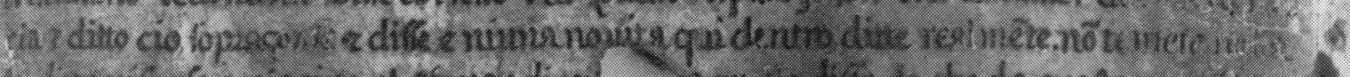

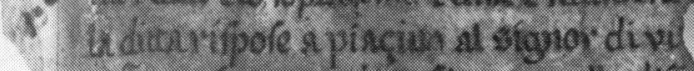

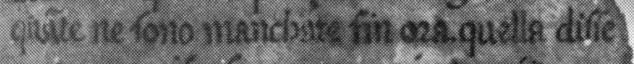

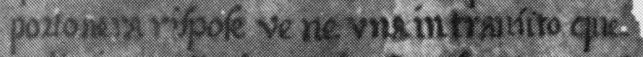

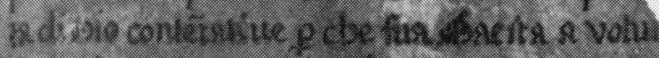

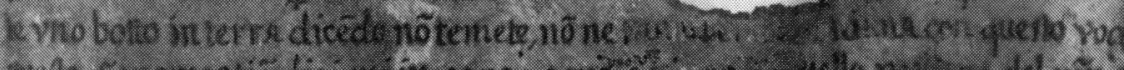

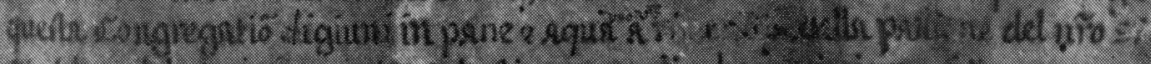

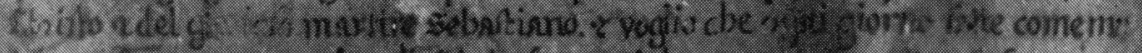

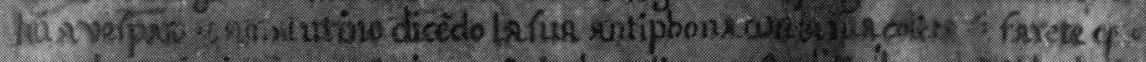

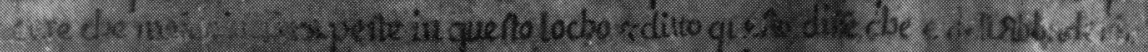

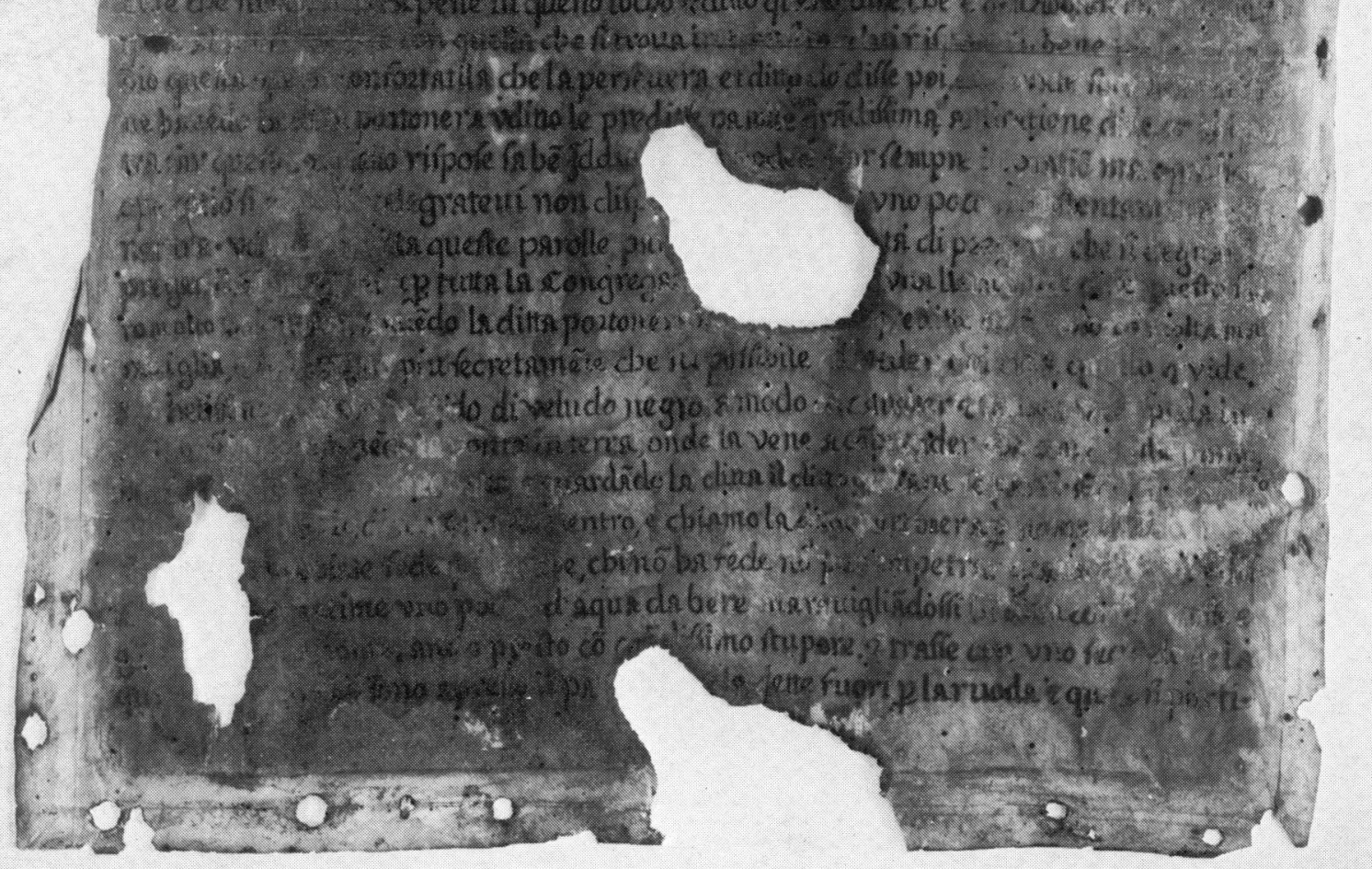

Figure 1.

MS Wellcome 808a recto (reduced). By courtesy of the Wellcome Trustees. 


\section{Short Articles}

is kept with the aforesaid nuns, written at that time [1464] in semigothic [that is, semi-humanistic] characters, and put in a frame."2 The text of the present manuscript has minor variants from that transcribed and published in 1788, possibly as a result of inaccurate transcription at that time: the present parchment is badly rubbed, and the text in many places nearly illegible; on the other hand much of the text has been preserved by someone who has traced over the more legible letters in black ink. The convent was suppressed in 1806, and its possessions, including over 226 paintings, were dispersed. ${ }^{3}$ The present manuscript was presumably taken from its frame, folded along the line of the crease, and used as the front end-paper of a book having, in an unidentified library, the press-marks mentioned above. From there it reached the Wellcome collection by paths unknown, and is now MS. 808a in the library of the Wellcome Institute for the History of Medicine. ${ }^{4}$ In the following translation of the manuscript, parts of the text which are now completely lost because of holes in the parchment are supplied, perhaps unreliably, from the 1788 transcription $^{5}$ and are enclosed in round brackets.

\section{WELLCOME MS 808a}

In the name of our Lord Jesus Christ and of (the glorious) virgin Mary and of the glorious martyr saint Sebastian, the year one thousand (four hundred) and sixty-four, the eighth day of July. It having pleased the Lord God to visit with plague our monastery of Santa Croce of Giudecca, and four sisters having already been lost, and the fifth was on her death-bed, and a portonera** being within the parlour, there was a knock at one of the windows. And the said woman replied, "Thanks be to God", and the reply came back to her, three times, "Thanks be to God for ever, sister", adding, "What is troubling you that you should be so saddened?"

The said portonera, marvelling, started to think who it could be that knew without seeing her that she was saddened. She said, "Who are you?" He replied, "I am a cavalier of the King of France", and that said, continued and said, "Is there no news here within?" He said, "Come, fear not." The said woman replied, "It has pleased the Lord God (to visit us with it.)" He said, "With this plague? How many have been lost from it up to now?" She said, "(Four." The) said man asked whether there were no more. The said portonera replied, "One is on her death-bed." He (said), "You are not content with the will of God. Be content, because His Majesty has wished this to happen here." And having put down the point [of his sword] he struck the ground saying, "Fear not. No more of them shall be lost. With this [stroke] I wish that this whole congregation fast on bread and water on one Friday [a year] in reverence of the passion of our Lord Jesus Christ and of the glorious martyr Sebastian. And I wish that every day you commemorate him evening and morning, saying his antiphon with his collect. If you do this be sure that there will never be plague in this place again." And that said, he said, "What is the Abbess doing?" The said woman replied, "At present she is with her who is on her death-bed." And he replied, "She does well. This work pleases God greatly. Comfort her, that she persevere." And that said, he then said, "And worship without respite." The said portonera, having heard the aforesaid words with the greatest surprise, said, "But who could do that?" And he replied, "The Lord knows full well that you cannot be always at worship. But any good work is worship in His eyes. Cheer up: it does not displease (God if you give) a little sustenance to nature."

The said woman, hearing these words, seemed to be obliged to beg him that he would deign to pray to the Lord for her and for all the congregation, (and so she did. And in) a cheerful voice he said, "I shall do that most willingly."

**Nun acting as a concierge. 


\section{Short Articles}

The said portonera, having (heard all the) aforesaid things, remained in great wonder, and thought secretly of a $w$ ' $y$ by which it would be possible to see who the man was. And she saw a most beautiful youth dressed in black velvet in the manner of a knight, and he was holding a sword in his hand, with a sheath, holding the point on the ground, whence it dawned on her that it was with that point that he had given the abovementioned blow. And with the said woman looking on, the said young man departed.

And having gone out the parlour, he came back in again, and called the said portonera by name, saying, "Sister Scholastica, have faith, because whoever does not have faith cannot be granted grace from God." And he said, "Please give me a little water to drink." The said woman, wondering how he could know her name, went straight away in the greatest amazement, and drew a bucket of water from the well which is next to the parlour, gave it to him outside by means of the wheel, and he departed.

The encounter took place at the door of the parlatorio, the outer hall of a convent where the nuns could speak of strangers through a grating but could not see them. There were windows, as the manuscript tells us, but they were probably too high in the wall for someone at ground level to look through them at another person at ground level on the other side: the nun presumably climbed up to look out. The "wheel" on which she gave out the bucket of water was a revolving door customarily used in convents for such purposes. The reader assumes until the beginning of the last paragraph of the translation above that the knight must have stayed outside the parlour; but then we are told that "having gone out of the parlour he came back in again" (Et essendo vssito fuora [del pa]rlatorio, di nouo torno dentro). The visitor's guess, if such it was, that the nun's name was Scholastica was not remarkable: Benedictine nuns were commonly called Scholastica, after St. Benedict's sister.

In spite of the visitor's claim that he was only a knight of the King of France, he was immediately identified with St. Sebastian, and his instructions were fully obeyed. ${ }^{6}$ During the next hundred years, up to 1564 , there were fourteen outbreaks of plague in Venice and environs, ${ }^{7}$ none epidemic. Whether Santa Croce was affected, I have not discovered. The anonymous biographer of the abbess says it was not, ${ }^{8}$ but one might surmise evidence to the contrary in the fact that the apparition seems to have been almost totally forgotten, although the framed parchment was of course preserved.

In the summer of 1575 plague again appeared in Venice, and continued sporadically until December. Having died out for two months, it reappeared in February or March 1576 and by June it was still present in Venice, though not especially virulent. ${ }^{9}$ During this time, the convent of Santa Croce is said to have remained unharmed, in accordance with "St. Sebastian's" prophecy as recorded on the parchment. ${ }^{10}$ This fact came to the attention of a printer, who published a broadsheet about the miraculous immunity of the convent. ${ }^{11}$ The public reacted to the broadsheet as if it had described a new miracle. From 26 June 1576, crowds crossed the lagoon to Giudecca to drink water from the well from which the "saint" had drunk. The well had to be worked from morning to night-fall to satisfy them. On one occasion they broke through the doors of the convent, and for some days a captain and troop of guard were called in to protect it. Eventually, part of the wall of the courtyard was taken down to allow construction of a conduit to dispense the water to outsiders. ${ }^{12}$

As noted, the crowds began to make for Santa Croce on 26 June 1576. From the 


\section{Short Articles}

lectures of Hieronymus Mercurialis (1530-1606), then professor of medicine at Padua, we discover that, "from about the middle of July [1576] all the symptoms [of plague] became more painful, many sick people appeared, deaths were more frequent. And all these things took on an increase throughout August, September, and also the beginning of October; in which months, if all factors be carefully assessed, it may be decided without difficulty that the sickness was at its full strength."13 It was unfortunate for Santa Croce that the new-found celebrity of its "miracle" should have been followed by this grave worsening of the plague. But in compensation for that failure, Venetians could see that, as the new church of the Redentore, being built as a prayer-offering for release from plague, arose on the site next to Santa Croce, so the plague died miraculously away. ${ }^{14}$ In the late eighteenth century, peasants were still coming over from the mainland to collect supplies of the holy well-water as a prophylactic against cattle-plague. ${ }^{15}$

\section{SUMMARY}

Many of the remedies for bubonic plague recommended by medieval physicians did little or no good, and this encouraged the popular belief that the disease might be cured by pilgrimages and worship. An example of this belief is found in the text of Wellcome MS. 808a, which was formerly in the Benedictine convent of Santa Croce della Giudecca, Venice. The text describes an incident which occurred at that convent during the plague of 1464. A man who claimed to be a knight of the King of France appeared to one of the nuns, sister Scholastica. He questioned her, praised the abbess for tending the sick, and advised the nuns to fast, and to pray to St. Sebastian. If they did so, he declared, the convent would be free of plague for all time. He then drank a cup of water from the well and departed. He was immediately identified with St. Sebastian, and the incident was recorded in the present manuscript. A translation and a photograph of the manuscript are given. During the plague of 1575-1576, the story of the apparition was revived, and many people went to the convent to drink the well-water in the hope that it would confer immunity from plague, a hope that was later conspicuously refuted.

\section{ACKNOWLEDGEMENTS}

I thank Drs. C. H. Talbot and Renate Burgess for their help.

\section{REFERENCES}

1. Karl Sudhoff, 'Pestschriften aus den ersten 150 Jahren nach der Epidemie des “Schwarzen Todes", 1348', Arch. Gesch. Med., 1910-1925, 4-17: passim. (For page references see: Grethe Herbrand-Hochmuth, 'Systematisches Verzeichnis der Arbeiten Karl Sudhoffs', ibid., 1934, 27: 175.) Dorothea Waley Singer and Reuben Levy, 'Plague tractates', Ann. med. Hist., 1917, 1: 394-411. L. F. Hirst, The conquest of plague, Oxford, Clarendon Press, 1953, pp. 38-45.

2. [Anonymous], Memorie della vita della B. Eufemia Giustiniani monaca benedettina ed abbadessa in Santa Croce della Giudecca dedicate alle Venete dame, Venice, Giuseppe Viezzeri, 1788, pp. 102-103.

3. Alvise Zorzi, Venezia scomparsa, 2 vols., Milan, Electa editrice, 1972, vol. 2, p. 498. 


\section{Short Articles}

4. S. A. J. Moorat, Catalogue of western manuscripts on medicine and science in the Wellcome Historical Medical Library, 2 vols. in 3, London, Wellcome Institute of the History of Medicine, 1973, vol. 2, p. 1477.

5. Op. cit., note 2 above, pp. 100-102.

6. Ibid., p. 35.

7. Ernst Rodenwaldt, Pest in Venedig 1575-7, Heidelberg, Springer-Verlag, 1953, p. 66, n. 1.

8. Op. cit., note 2 above, p. 36.

9. Hieronymus Mercurialis, De pestilentia, Venice, P. Meietus, 1577, chapter II, p. 4.

10. Op. cit., note 2 above, p. 36.

11. Emmanuele Cigogna possessed a copy of the broadsheet: see E. A. Cigogna, Delle inscrizioni veneziane, 6 vols. in 7, Venice, [the author and others], 1824-61, vol. 4, p. 139.

12. Op. cit., note 2 above, pp. 103-104.

13. Mercurialis, op. cit., note 9 above, pp. 4-5.

14. Rodenwaldt, op. cit., note 7 above, p. 139.

15. Op. cit., note 2 above p. 107 